Niepełnosprawność. Dyskursy pedagogiki specjalnej

\title{
Dialektyka troskliwości i pedagogiczne praktyki wspierania rozwoju a filozoficzne koncepcje "myśli słabej" (uwagi na marginesie hermeneutyki H.-G. Gadamera i G. Vattimo)
}

Hermeneutyczne doświadczenie innego bytu ma zawsze wymiar etyczny i może przybierać rozmaite kształty określające różne rodzaje relacji, które stanowią - jak określa je Gadamer - pewne sposoby doświadczania Ty. Jednym z nich jest relacja wyrastająca z „dialektyki troskliwości”, stanowiącej formę dążenia do panowania nad drugą osobą, gdy wydaje nam się, iż wiemy lepiej kim ona jest i czego potrzebuje. Jednym z podstawowych celów procesu kształcenia jest wspieranie rozwoju uczniów. Jednakże zarówno pojęcie wsparcia, jak i pojęcie rozwoju, mają dyskursywny i wieloznaczny charakter, a ich znaczenia są konstruowane w toku różnorodnych praktyk edukacyjnych. Myślenie pedagogiczne zazwyczaj domaga się budowania powiązań pomiędzy sferą badawczych, teoretycznych interpretacji zjawisk a obszarem pragmatycznych działań, czyli tzw. praktyką pedagogiczną. Dla pedagogicznej praxis szczególnie atrakcyjna wydaje się być wiedza jednoznaczna, racjonalna, pewna i uporządkowana, umożliwiająca wyciąganie wniosków i prowadząca do rozwiązania problemów oraz uzyskania określonych rezultatów. Wymienione cechy charakteryzują to, co można określić jako „myśl silną”, stanowiącą fundament dla praktyki pedagogicznej. Kategoria „słabości”, , konstytuująca typ refleksji kształtujący „myśl słabą”, inspirowana koncepcjami M. Heideggera, odnosi się do pojęcia "osłabienia”, rozumianego jako przygodność bytu, myśli i kultury. Myśl słaba, niepewna, niejasna, wieloznaczna, o płynnych granicach zamazujących wyraźne kształty pojęć, dynamiczna, znajdująca się w ciągłym ruchu i przekraczająca zastane struktury wiedzy, nie może udzielić nam wiążących odpowiedzi. Nie daje wskazań co i w jaki sposób robić, nie rozwiązuje praktycznych problemów, nie dysponuje mocą budowania konkretnych porad zapewniających skuteczne działanie. Taki rodzaj poznawczej refleksji wydaje się być nie tylko kłopotliwy, ale wręcz zbędny dla pedagogicznej praktyki. Jednakże przekroczenie pola pragmatycznych działań może prowokować jakościową zmianę myślenia, przemieszczającą poznanie w stronę logiki wielości i prowadzącą do bardziej świadomego działania w codziennej pracy pedagogicznej.

Słowa kluczowe: dialektyka troskliwości, wsparcie pedagogiczne, myśl słaba 


\title{
Dialectics of solicitude and the pedagogical development supporting in the perspective of a "weak thought": reflexion on the margins of H.-G. Gadamer and G. Vattimo hermeneutic philosophy
}

\begin{abstract}
Hermeneutical experience of Other is always a kind of ethical experience and can shape the different relations which - according to Gadamer - are the various ways of experiencing of You. The relation rooted in the dialectics of solicitude is a kind of domination act as we be better know who the Other is and what he/she needs. One of the basic goals in the education process is to support the pupils' development but the categories of development and pedagogical support are discursive and polisemantic concepts, constructed in many different educational practices. Pedagogical thinking intensively demands the links between the sphere of "theoretical" interpretations of phenomena and the pragmatic activity area. For the pedagogical praxis the clear, confident, rational and structured knowledge seems to be especially attractive. Knowledge which makes possible to solve the problems and leads to obtain the particular results. All these features shape what we know "strong thought". While the category of weakness, which constitutes the reflexion characteristic for "weak thought" and inspired by M. Heidegger philosophy, refers to the concept of fortuitousness the existence, thinking and culture. The weak, unconfident, polisemantic and unclear thought, having the liquid borders which blur the clear shapes of concepts, being in a constant movement and exceeding the stable structures of knowledge. This kind of knowledge is not able to give us the unambiguous answers and simple instructions, it does not solve the practical problems and has no power to give the concrete advice ensuring the effective treatment. Such kind of cognitive reflexion seems to be not only inconvenient but simply useless for the educational practice. But going out of the practical activities can provoke the change of quality which can shift our thinking in the direction of multiplicity and heterogeneity logic. It also gives a chance to act in a more conscious way in our everyday, educational work.
\end{abstract}

Keywords: dialectics of solicitude, pedagogical support, weak thought

\section{Dialektyka troskliwości i pedagogiczne wsparcie}

H.-G. Gadamer pisał, iż nasze „bycie w świecie” jest istnieniem i życiem w rozmowie, relacją z otaczającymi nas bytami. W tym sensie można mówić o uniwersum rozmowy, dialogu ze światem, który realizuje się w podstawowej relacji międzyludzkiej, relacji wiążącej „ja“ z „ty“. Hermeneutyczne doświadczenie innego bytu, bycia w rozmowie z drugim człowiekiem ma zawsze wymiar etyczny i może przybierać rozmaite kształty określające różne rodzaje relacji, które stanowią - jak określa je Gadamer - pewne sposoby doświadczania Ty. Jednym z nich jest relacja wyrastająca z "dialektyki troskliwości,", stanowiącej formę dążenia do panowania nad drugą osobą. Rozumienie innego człowieka jest w tej sytuacji samoodniesieniem, co sprawia, iż wydaje nam się, że go znamy i rozumiemy lepiej niż on sam siebie jest w stanie poznać i zrozumieć [1993, s. 334]. Co za tym idzie, lepiej wiemy co jest dla niego dobre, właściwe i odpowiednie, co powinien myśleć i robić, jak działać, w jaki sposób odnosić się do świata. Tego rodzaju autorytarna forma 
troskliwości cechuje relacje oparte na "stosunku pedagogicznym“, w których zachodzi dominacja jednej strony nad drugą (np. relacja między dorosłym i dzieckiem, nauczycielem i uczniem, lekarzem i pacjentem itp.). I choć jest to rodzaj doświadczenia dość powszechnie przenikającego życie społeczne i stosunki między ludźmi, w sposób szczególnie wyrazisty zaznacza swą obecność w strukturach i sposobie funkcjonowania systemu edukacji.

Zarówno w literaturze przedmiotowej, jak i różnego rodzaju aktach prawnych regulujących funkcjonowanie systemu edukacji, powszechne jest uznanie, iż jednym z podstawowych celów procesu kształcenia jest wspieranie rozwoju uczniów. Szczególnie istotne i eksponowane staje się to założenie w odniesieniu do podmiotów definiowanych jako uczniowie ze specjalnymi potrzebami, czyli uczniowie, którzy z uwagi na występujące u nich różnego rodzaju trudności i ograniczenia wynikające z niepełnosprawności, wymagają dostosowania programu, metod i form kształcenia do ich potrzeb i możliwości, i którzy kategoryzowani są w grupach zależnie od rodzaju/typu niepełnosprawności. Abstrahując w tym momencie od konstruktu pojęciowego "specjalne potrzeby edukacyjne“ , który wzbudzać może pewne kontrowersje, niejednoznaczne jest pojęcie samego rozwoju [zob. Kohlberg, Mayer 1993], a co za tym idzie, także kategorie „wspierania rozwoju“ czy "wsparcia edukacyjnego“.

Pojęcie „wsparcia“ jest zazwyczaj rozumiane jako realizacja istotnych celów edukacji i w takim sensie stanowi pewnego rodzaju praktykę pedagogiczną, uruchamiającą jednak bardzo zróżnicowane, często nieświadome i nieartykułowane wprost przedsądy, kształtujące przedrozumienie zjawisk. Jak zauważa D. Klus-Stańska [2008, s. 40] kategoria pedagogicznego wsparcia (oraz pokrewnych sformułowań) jest polisemantyczna i w zależności od leżących u jej podstaw założeń może oznaczać bardzo różne rzeczy i w zupełnie odmienny sposób kształtować zarówno wizerunek samego dziecka/ucznia, rozumienie tego czym jest rozwój, jak i postrzeganie systemu edukacji oraz jego zadań. Jest to bowiem kategoria dyskursywna, która w toku głębszej analizy odsłania zaangażowanie w różne teorie i ideologie edukacyjne. Przyglądając się zatem z uwagą znaczeniom jakie są nadawane pojęciu wsparcia w praktyce realnych działań pedagogicznych, można wyodrębnić kilka podejść bazujących na odmiennych paradygmatach, które definiują kształt i reguły edukacyjnej rzeczywistości, często „....przyjmowanych na poziomie zdroworozsądkowym, w metodycznej idealizacji lub demagogicznym upraktycznieniu" [tamże, s. 40].

Kategoria wsparcia może zatem oznaczać: kierowanie postrzeganym liniowo rozwojem dziecka $w$ procesie przyswajania określonych $w$ treściach kształcenia wiadomości i umiejętności (podejście funkcjonalistyczno-behawioralne); uczenie „bycia sobą“, realizowane w odniesieniu do poglądu, iż dziecko/uczeń dysponuje naturalną tendencją do indywidualnego rozwoju (podejście humanistyczno- 
-adaptacyjne); organizowanie środowiska uczącego, tak by stworzyć optymalne warunki samodzielnego konstruowania poznawczych modeli rzeczywistości (podejście konstruktywistyczno-rozwojowe); współdziałanie z dzieckiem i pomaganie mu w procesie wytwarzania znaczeń nadawanych rzeczywistości (podejście konstruktywistyczno-społeczne); emancypację i wyzwolenie z ograniczeń narzucanych $\mathrm{w}$ toku edukacji sposobów interpretowania rzeczywistości (podejście krytyczno-emancypacyjne). Jak widać rozumienie kategorii „wspierania rozwoju“ dziecka/ucznia/wychowanka ukazuje bardzo szeroki wachlarz potencjalnych interpretacji, począwszy od całkowitego "sterowania“ drugą osobą, jej sposobem myślenia i działania, a skończywszy na uczeniu krytycznego myślenia, ujawniającego symboliczną przemoc obecną $w$ praktykach edukacyjnych i roszczenie prawa do wyrażania własnych, samodzielnych sposobów rozumienia rzeczywistości [tamże, s. 41-44].

W praktyce edukacji specjalnej pojęcie wsparcia wydaje się nabierać szczególnie istotnego znaczenia ze względu na fakt, iż podmiotami procesów kształcenia i wychowania są dzieci/uczniowie z różnego rodzaju zaburzeniami i nieprawidłowościami rozwoju. Jeśli uznamy, że celem edukacji specjalnej jest kształcenie zgodne z ich potrzebami i dostosowane do indywidualnych trudności w uczeniu się, to wspomaganie dziecka w osiąganiu określonych celów rozwojowych wysuwa się na pierwszy plan. Sposób rozumienia pojęć wparcia i wspomagania rozwoju wiąże się zazwyczaj z uruchamianiem specjalistycznych, profesjonalnych działań ukierunkowanych na osiągnięcie określonych celów terapeutycznych i edukacyjnych. Obejmują one diagnozę stanu wyjściowego, stanowiącą bazę dla określenia silnych i słabych sfer rozwoju i funkcjonowania dziecka, określenie jego potrzeb w zakresie wsparcia, sposobów i warunków udzielanej pomocy. Wsparcie pedagogiczne w odniesieniu do dzieci/uczniów ze specjalnymi potrzebami edukacyjnymi przyjmuje często formę pedagogicznej interwencji w różne sfery funkcjonowania dziecka i jego środowiska rodzinnego, a także szkolnego, której celem jest przede wszystkim skuteczne działanie i usunięcie trudności [zob. np. Chrzanowska 2015, s. 438-458].

\section{Działanie pedagogiczne w aspekcie „myśli silnej”}

Myślenie pedagogiczne, niejako ze swej natury, zwłaszcza jeśli odniesiemy je do praktyk edukacji specjalnej, które silnie akcentują aspekty terapeutycznorehabilitacyjne, intensywnie domagają się budowania powiązań pomiędzy sferą badawczych, teoretycznych interpretacji zjawisk, a obszarem pragmatycznych działań, czyli tzw. praktyką pedagogiczną. Gdy mamy do czynienia ze zdarze- 
niem, sytuacją „odstępstwa od rozwoju“, potrzeba praktycznej, efektywnej interwencji wydaje się być szczególnie ważna i uzasadniona. Wyraźnie uwidacznia się zatem atrakcyjność wiedzy jednoznacznej, racjonalnej, pewnej i uporządkowanej, umożliwiającej wyciąganie wniosków i prowadzącej do rozwiązania problemów. Wymienione cechy charakteryzują to, co można określić jako „myśl silną“, stanowiącą fundament dla praktyki pedagogicznej [zob. Męczkowska 2003] i przeciwstawianą temu, co G. Vattimo nazywał zakorzenioną w filozofii różnicy, „myślą słabą“ [2003]. Myśl pewna, konkretna, efektywna, mająca nas prowadzić do osiągania określonych rezultatów, tworzy obszar wiedzy naukowej, która kształtuje sferę profesjonalnych działań, pozwala skutecznie wspierać i pomagać. Taka interpretacja pedagogicznego myślenia jest bliska rozumieniu kategorii wsparcia w języku pojęć definiujących wyróżnione przez D. Klus-Stańską podejście funkcjonalno-behawioralne i humanistyczno-adaptacyjne, choć częściowo obecne jest także, w mniejszym lub większym stopniu, w pozostałych ujęciach.

Myśl silną, powiązaną ze sposobem ujmowania rzeczywistości charakterystycznym dla strukturalizmu, A. Męczkowska określa jako rodzaj „poznawczej dysfunkcji“, przejawiającej się w „...przywiązaniu do klasyfikującego, upraszczającego, opozycjonującego porządkowania cech bytu podlegającego poznaniu, przy jednoczesnym założeniu możliwości poznania obiektywizującego [...]" [2002, s. 8-9]. Zaangażowanie poznawcze zakłada zdolność do „porządkowania i przedstawiania“, tworzenia reprezentacji prawdziwej natury rzeczywistości, których celem jest „osiągnięcie ostatecznego porządku“ i poznanie zasad regulujących jej strukturę, co pozwoli rozwikłać nierozwiązane jeszcze zagadki i odkryć dotąd nieodkryte tajemnice. Stawia się tu znak równości pomiędzy rzeczywistością i jej opisem [tamże, s. 11], której towarzyszy przekonanie, iż dzięki temu nasze działania uzyskają sprawczą moc. Refleksja charakteryzująca myśl silną przenika pedagogikę, co zauważyć można w koncepcjach określających przedmiot jej zainteresowania, wychowanie, jako dążenie do „efektu homeostazy“ , „... w którym relacja pomiędzy podmiotem a światem nabiera cech harmonijnego, zrównoważonego związku" [tamże, s. 13].

W odniesieniu do pedagogiki specjalnej może to np. przejawiać się w realizacji celów ukierunkowanych na normalizację warunków życia i wspomaganie rozwoju, uczenia się i usamodzielniania osób z niepełnosprawnością, tak aby mogły one włączyć się w różne obszary życia społecznego. Realny świat stawia jednak opór, pomimo starań i wielu pozytywnych zmian, dostrzegana różnica związana z uszkodzeniami ciała/sfery poznawczej, uparcie nie chce rozmyć się w nurtach życia społecznego i dość skutecznie hamuje możliwość osiągnięcia pożądanego stanu równowagi. Świadczą o tym choćby niepowodzenia kształcenia integracyjnego i edukacji włączającej, znikoma obecność osób niepełnosprawnych na rynku pracy czy w sferze publicznej. A. Męczkowska pisze, iż projekt wychowania 
osadzony w myśli silnej strukturalizmu za punkt wyjścia przyjmuje „matrycę Tego Samego", co sprawia, że ustrukturyzowana zgodnie z nią przestrzeń działania pedagogicznego, jest obszarem, w którym zachodzi zobiektywizowany i proces wychowania mający prowadzić do uzyskania określonych rezultatów.

Autorka zauważa, iż ceną, jaką płaci pedagogika za iluzję uporządkowanego świata, jest „....rozdział pomiędzy pedagogicznym centrum, podejmującym kwestie "pedagogiki normalnych», a jego peryferiami, obejmującymi «pedagogikę heterogenicznych, czyli marginalizowanych»" [tamże, s. 14]. I nie ma tu istotnego znaczenia czy owi marginalizowani wychowankowie podlegają systemowi kształcenia specjalnego $\mathrm{w}$ odrębnych instytucjach czy w systemie kształcenia integracyjnego albo edukacji włączającej. Ich swoistość i odrębność jest odtwarzana w samych założeniach organizujących system edukacji i praktykach działania, które kształtują funkcjonowanie uczniów z różnego rodzaju trudnościami i ograniczeniami. Analizy opisujące sposoby i teorie konstruowania kategorii „specjalnego programu“ $i$ "specjalnego ucznia“ (czy też ucznia ze specjalnymi potrzebami) oraz rolę, jaką pełnią $\mathrm{w}$ społeczeństwie możemy odnaleźć $\mathrm{w}$ literaturze z obszaru socjologii edukacji [Milofsky 1997].

\section{„Słabośćc pedagogicznego myślenia w relacji wychowawczej}

Myśl słaba, osadzona $\mathrm{w}$ postheideggerowskiej ontologii kwestionującej założenia filozofii metafizycznej, jest myśleniem, które nie buduje silnych kategorii opisujących rzeczywistość. Jak pisze G. Vattimo: „Myślenie prawdy nie jest myśleniem, które «tworzy fundamenty» (...) lecz myślą, która obnażając ułomność i śmiertelność jako to, co właśnie określa bycie, usuwa te fundamenty. (...) przemyśliwanie, które jest autentycznym myśleniem (jako że nie jest nim ani naukowe mierzenie, ani techniczne porządkowanie), nie może korzystać z logiki opartej na zasadach sprawdzalności i rygorze dowodzenia..." [2003, s. 132-133]. Myśl słaba jest przede wszystkim słaba ontologicznie, ze względu na sposób pojmowania pojęć bycia i prawdy, nie jest zatem myślą ze swej istoty przewyższającą sferę praxis [tamże, s. 135]. Używając języka filozofii ponowoczesnej, nie jest myślą stawiającą roszczenia do bycia prawdziwą, słuszną czy uniwersalną. Jest myślą przygodną, która jedynie się nam przydarza, czasami prześwituje zza zasłony zdarzeń i zjawisk, ukazuje przedkategorialne ślady bycia-w-świecie.

Kategoria "słabości“ konstytuująca typ refleksji kształtujący „myśl słabąa, inspirowana koncepcjami M. Heideggera, odnosi się do pojęcia "osłabienia“, rozumianego jako przygodność, wydarzania się bytu, myśli i kultury. Jak zauważa A. Zawadzki, jest pewnego rodzaju metaforą filozoficzną, którą można ukazać 
z bliższej perspektywy, odwołując się do jej wymiaru ontologicznego, epistemologicznego i kulturowego [2009, s. 14-18]. W aspekcie ontologicznym byt słaby/ osłabiony to byt, który utracił swą esencjonalność i substancjonalność, funkcję podstawy i fundamentu jakim był w metafizycznych ujęciach absolutu radykalnie wykraczającego poza świat empiryczny. Epistemologiczny wymiar słabości wiążę się z możliwościami poznawania rzeczywistości i statusu definiujących ją pojęć, charakteryzujących się niepewnością i ograniczonością. Natomiast aspekt kulturowy dotyczy próby analizy i interpretacji współczesnej kultury, która opisywana jest za pomocą pojęć przygodności, tymczasowości, rozpadu trwałych struktur, stabilności i zakorzenienia, co prowadzi również do podważenia struktur „mocnego", autonomicznego podmiotu ${ }^{1}$. W obszarze etyki kategoria słabości wyraża się w odejściu od normatywnych zasad regulujących sferę moralności i postawie egzystencjalnej odwołującej się do pojęcia odpowiedzialności w relacji z innym, jak ma to miejsce np. w koncepcjach E. Levinasa i jego epifanii Twarzy Drugiego [Levinas 1991].

A. Zawadzki charakteryzuje myśl słabą, zwracając przy tym uwagę, iż choć wywodzi się ona z filozofii i stosowana jest głównie do analizy problemów filozoficznych, ma jednak szersze znaczenie i może także stanowić punkt odniesienia dla badań eksplorujących rozmaite zjawiska kultury nowoczesnej i ponowoczesnej, stanowiąc kontekst ich interpretacji. Myśl słaba jest zatem pewną ogólną tendencję myślową, za pomocą której możemy nazywać i wyrażać klimat intelektualny epoki późnej nowoczesności, charakteryzujący się epistemologiczną niepewnością. Dzięki wieloznaczności i braku „mocnej“ definicji zjawisk może obejmować różne obszary poznania i doświadczenia. Jej istotną cechą jest także możliwość przekraczania własnej, słabej i niepewnej kondycji i próba objęcia refleksją tych obszarów myślenia, które wymykają się silnym opozycjom i dychotomicznym strukturom kształtującym porządek rzeczywistości [tamże, s. 12-14]. Krytyczny potencjał cechujący myśl słabą odnaleźć możemy w literaturze pedagogicznej, ukazującej współczesne nurty pedagogiki krytycznej, radykalnej, zaangażowanej $\mathrm{w}$ proces demistyfikacji dominujących narracji i transformacji praktyk działania, pedagogiki poszukującej sfery „pomiędzy“ dostępnymi strukturalnymi identyfikacjami [zob. np. Giroux 2011; McLaren 2014].

Myśl słaba, niepewna, niejasna, wieloznaczna, o płynnych granicach zamazujących wyraźne kształty pojęć, dynamiczna, znajdująca się w ciągłym ruchu i przekraczająca zastane struktury wiedzy, nie może udzielić nam wiążących odpowiedzi. Nie daje także prostych wskazań co i w jaki sposób robić, nie roz-

1 O zmianie znaczeń kategorii podmiotu w odniesieniu do pola pedagogiki specjalnej i niepełnosprawności jako przedmiotu jej zainteresowań piszę m.in. w tekście: Niepetnosprawność i pedagogika. Pytanie o podmiot a kwestia tożsamości i zmiany paradygmatycznej dyscypliny, "Studia z Teorii Wychowania", t. 2, 2011, nr 2, s. 267-283. 
wiązuje praktycznych problemów, nie dysponuje mocą budowania konkretnych porad zapewniających skuteczne działanie. Taki rodzaj poznawczej refleksji wydaje się być nie tylko kłopotliwy, ale wręcz zbędny dla pedagogicznej praktyki, w której mamy skutecznie realizować założone cele i zadania, efektywnie wspierać $\mathrm{w}$ rozwoju, uczeniu się, nabywaniu wiedzy i umiejętności, wspomagać w codziennym funkcjonowaniu. Jednakże przekroczenie pola pragmatycznych działań, rozwiązań i realizacji powoduje jakościową zmianę myślenia, przemieszczającą poznanie w stronę logiki wielości i różnorodności rozwiązań. Tak upragniona „myśl silna“ często bywa iluzją, jej siła i moc sprawcza może być pozorna i złudna. Pewność i jednoznaczność blokuje możliwość refleksji, myślowego ogarnięcia rzeczywistości i wyjścia poza utarte schematy poznawcze i wzorce działania. Blokuje także możliwość budowania w sferze pedagogicznych relacji takich doświadczeń, które tworzyłyby warunki nie tylko do realizacji zadań, ale także, a może nawet przede wszystkim, uważnego wsłuchania się w treści i znaczenia jakie niosą ze sobą indywidualne doświadczenia i opowieści naszych "podopiecznych“.

Relacja budowana w przestrzeni „myśli słabej“ $i$ „słabej etyki“ zbliża się do tego rodzaju doświadczenia drugiego człowieka, które H.-G. Gadamer nazywał doświadczeniem hermeneutycznym, polegającym na doświadczeniu "ty" rzeczywiście jako „ty“. Uważał je za najwyższy, autentyczny rodzaj doświadczenia, w którym rozpoznanie i uznanie drugiego konstytuuje postawę otwartości, pozwalającą drugiemu nas „zagadnąć“ i coś nam powiedzieć. Egzystencjalna postawa otwartości nie jest naznaczona tymczasowością danej sytuacji, lecz buduje ogólną postawę gotowości do słuchania i wzajemności [1993, s. 336]. Może zatem stać się szansą wysłuchania głosów, których do tej pory nie chcieliśmy/nie mogliśmy usłyszeć, a może nawet nie byliśmy świadomi, że mogą nam coś ważnego powiedzieć. Tworzy przestrzeń dla zaistnienia i wyartykułowania potrzeb tych, którzy z różnych powodów byli wykluczani z pola edukacyjnej wspólnoty, ustanawiającej reguły jej funkcjonowania i wzajemnych relacji (dziecko/uczeń/wychowanek/podopieczny/rodzic, ...). H.-G. Gadamer zauważa, że „....wychowanie jest wychowaniem siebie, kształcenie jest kształceniem siebie“, a to oznacza, że „...uczyć się można tylko w rozmowie“, od siebie nawzajem [2008, s. 258-259].

Pole wiedzy ukształtowanej w ramach "myśli słabej, daje szansę pojawienia się krytycznie ukierunkowanej refleksji nad własnymi praktykami działania i przepracowania różnych aspektów rozumienia tego czym jest/może być „wspieranie w rozwoju“, także dziecka/ucznia z niepełnosprawnością. A to z kolei może prowadzić do bardziej świadomego działania w codziennej, pedagogicznej pracy. Warto chyba zatem podjąć taki wysiłek. 


\section{Bibliografia}

Chrzanowska I. (2015), Pedagogika specjalna. Od tradycji do wspótczesności, Oficyna Wydawnicza „Impuls,, Kraków.

Gadamer H.-G. (1993), Prawda i metoda. Zarys hermeneutyki filozoficznej, Wydawnictwo „inter esse", Kraków.

Gadamer H.-G. (2008), Teoria, etyka, edukacja. Eseje wybrane, Wydawnictwa Uniwersytetu Warszawskiego WAW, Warszawa.

Giroux H. (2011), On critical pedagogy, Continuum International Publishing Group, New York.

Klus-Stańska D. (2008), Konteksty teoretyczne nadawania znaczeń przez dzieci. Wokót pytań o rozumienie pedagogicznego wsparcia [w:] Wspieranie rozwoju dzieci w procesie wczesnej edukacji, W. Puślecki (red.), Wydawnictwo Naukowe DSW, Wrocław.

McLaren P. (2014), Life in schools: An introduction to critical pedagogy in the foundations of education, Paradigm Publishers.

Milofski C. (1997), Sociology of special education [w:] International encyclopedia of the sociology of education, L. H. Saha (red.), Pergamon, Oxford.

Vattimo G. (2003), Dialektyka, różnica, myśl staba, „Teksty Drugie“, nr 5, s. 124-137.

Zawadzki A. (2009), Literatura a myśl staba, Universitas, Kraków. 